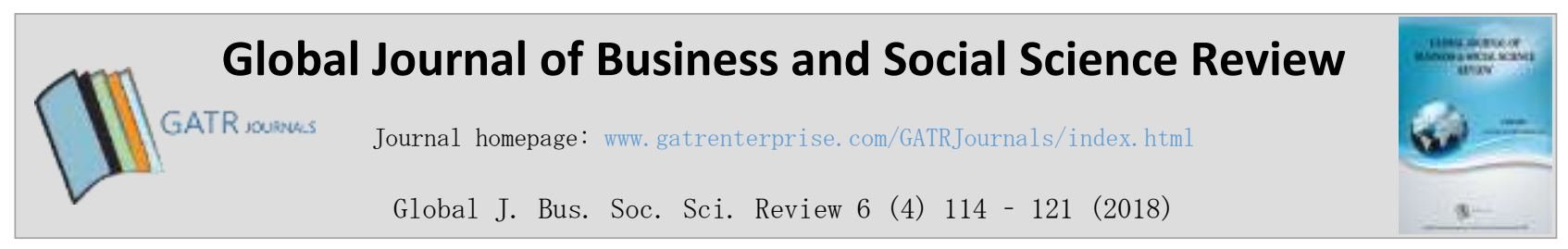

\title{
Conceptualizing ASEAN Tourism Brand: Towards A Coopetition Framework
}

\author{
Varintra Sirisuthikul * \\ Srinakharinwirot University, 114 Sukhumvit 23, 10110, Bangkok, Thailand
}

\begin{abstract}
Objective - This paper proposes an integrative framework in an attempt to conceptualize the branding of ASEAN tourism in a sustainable and unified approach based on the results collected from a sample of travellers visiting ASEAN destinations and tourism insights from NTOs or DMOs.

Methodology/Technique - A mixed method is used to combine the quantitative and qualitative phases. A survey of travellers visiting ASEAN destinations $(\mathrm{n}=480)$ is conducted with a mix of Asian travellers and Western travellers, as well as 10 in-depth interviews with NTOs or DMOs to obtain tourism insights.

Findings - The findings suggest that authenticity of the destination image is an integral part of ASEAN tourism. National Tourism Organizations (NTOs), Destination Marketing Organization (DMO) and other stakeholders of ASEAN tourism should adopt a coopetition framework and co-create a consistent and coherent positioning of the destination, while maintaining a competitive positioning of the nation, to achieve a sustainable brand of ASEAN tourism.

Novelty - The paper highlights the needs for ASEAN NTOs and DMOs to enable coopetition for all tourism stakeholders for the promotion of the ASEAN brand. The proposed framework is seen as transformative in its ability to bring about collaborative and sustainable efforts to ultimately achieve an authentic ASEAN brand.

Type of Paper: Empirical.
\end{abstract}

Keywords: ASEAN Tourism Brand; Coopetition; Cooperation and Competition; Authenticity; NTOs; DMOs. JEL Classification: M38, L32.

\section{Introduction}

Tourism is considered to be a major socio-economic driver for growth and development (Brida \& Aguirre, 2010; Webster \& Ivanov, 2014), particularly for the ASEAN region, which is comprised of 10 member countries: Brunei, Cambodia, Indonesia, Laos, Malaysia, Myanmar, Philippines, Singapore, Thailand and Vietnam.

\footnotetext{
${ }^{*}$ Paper Info: Revised: August 11, 2018

Accepted: December 5, 2018

* Corresponding author: Varintra Sirisuthikul

E-mail: varintra.s@gmail.com

Affiliation: Faculty of Business Administration for Society, Srinakharinwirot University, Thailand
} 
While many ASEAN destinations have established their worldwide reputation, according to an ASEAN Brand Awareness Survey (2015-2016) by the ASEAN Tourism Marketing Working Group, the brand of the ASEAN region as a whole is under-explored and remains unknown to many global tourists (ATMS, 2017). The ASEAN Tourism Strategic Plan 2016 - 2025 emphasizes sustainable development. The aim is to draw attention to the value, diversity and shared characteristics of ASEAN tourist destinations. This raises the question of how ASEAN countries should be positioned and branded in their markets as a single destination (ATSP, 2016). With the complex nature of the tourism industry (Zavattaro, Daspit \& Adams, 2015), the challenges facing ASEAN National Tourism Organizations (NTOs) and Destination Marketing Organizations (DMOs) are tremendous, as ASEAN works towards one vision, one identity and one community.

Although destination branding literature has been developed since the late 1990s (e.g. Gnoth, 1998, Cai, 2002), research relating to ASEAN tourism is scarce (Wong, Mistilis \& Dwyer, 2011). To fill this gap, this study puts proposes a more integrative framework in an attempt to conceptualize the ASEAN tourism brand by adopting a coopetition approach. The framework presents a coopetition model which integrates the concepts of sustainability and partnership as it applies to the context of ASEAN tourism.

\section{Literature Review}

\subsection{ASEAN Tourism and Sustainability of Destination Brand}

ASEAN (Association of Southeast Asian Nations) was established on 8 August 1967. The region is comprised of 10 countries: Brunei, Cambodia, Indonesia, Lao, Malaysia, Myanmar, Philippines, Singapore, Thailand and Vietnam. Tourism is one of the most important cooperation areas within the ASEAN region and has been considered as a major socio-economic driver for growth and development. In one survey by the MasterCard Global Destination Cities Index, 8 destinations in Southeast Asia were among the top 20 destinations in the Asia Pacific by international overnight arrivals, which is 1. Bangkok (Thailand) ranked first, Singapore ranked second, Kuala Lumpur (Malaysia) ranked third, Phuket (Thailand) ranked sixth, Bali (Indonesia) ranked eighth, Pattaya (Thailand) ranked tenth, Siem Reap (Cambodia) ranked thirteenth and Phnom Penh (Cambodia) ranked nineteenth.

With the growing popularity of tourists visiting destinations in ASEAN or Southeast Asia, the brand of "ASEAN" is still unknown to many tourists. Of the 8,544 participating respondents surveyed by the ASEAN Tourism Marketing Group in 2016, 81.74\% were not familiar with the ASEAN brand "Southeast Asia feel the warmth" logo and tagline. Among these, the main source of information for the ASEAN tourism brand is the Internet $(63.45 \%)$. In addition, a study of the ASEAN brand, as perceived by tourism stakeholders of the member states, revealed that the influence of the ASEAN brand is relatively weak, particularly in terms of tourism destination branding, as compared to the strength of the nation brands of some members (Dinnie, Melewar, Seidenfuss \& Musa, 2010).

The notion of destination branding involves the establishment of an identity of the destination brand; as a result, countries, regions, or cities become an integral part of the brand of the destination (De Chernatony, 2010; Morgan et al., 2011). Moutinho et al. (2013) and Pareja-Eastway et al. (2013) suggest that organizations in charge of designing branding strategies should concentrate their effort on: (1) content: focusing on the interaction between the traveler/tourist and the destination and engaging the traveler/tourist with the destination branding process; (2) context: tailored approaches and context sensitive strategies that integrate traveler-generated content; and (3) co-creation: co-creating value through the traveler and the destination and destination branding through co-creation (i.e. using the traveler as active participant in the branding process). Oliveira and Panyik (2014) assert that traveler-generated content is likely to generate greater brand value if it is integrated into the destination branding strategy. Meanwhile, over promotion of a destination may result in "staged authenticity" which is brought about by the commoditization of culture in mass tourism (Zhu, 2012). On the other hand, Hassan (2000) and Ruhanen (2013) stress that to ensure sustainable tourism, local environments or cultures must not be traded for increased tourism. The aim of 
sustainable tourism is to ensure that tourism development brings a positive experience for all stakeholders, including local people, tourism companies and the tourists themselves.

\subsection{Stakeholder Engagement Through Public-Private-People Partnership}

Tourism is a complex phenomenon involving many players. The fragmented nature of the tourism industry requires a substantial degree of collective effort and collaboration among the variety of different players in destination marketing (Grangsjo, 2003; Vernon et al., 2005; Wang, 2008; Wang and Fesenmaier, 2007). The ASEAN Tourism Marketing Strategy (ATMS) 2017-2020 has identified partnership as a key strategic direction to assist in the promotion and development of the Southeast Asian region (ATMS, 2017). Selsky and Parker (2005) urge that more research on multilateral partnerships is needed in order to strengthen the conceptual underpinnings of tourism stakeholders. In spite of the significant contribution that tourism makes to the region, intergovernmental collaboration in tourism among ASEAN nations has received little attention (Wong, Mistilis \& Dwyer, 2011).

Partnerships are often led by a convener, and they may be more successful when this facilitator is perceived to have legitimate authority (Parker, 2000). For the tourism industry, public sectors or government entities often play a key role in tourism development as they regulate policies and they have the ultimate responsibility in addressing societal issues which leads to sustainability. Furthermore, in many cases, governments are provide funds for tourism development projects, particularly in developing countries. Governments in many countries endorse the use of partnership arrangements in planning for tourism and infrastructure development. For the private sector, one of the advantages of partnering with public sector players is the ability of the government to bring together stakeholders representing interests on national, regional, and local scales, whether it be locally owned hotel operators or high-investment resort projects.

For people in the communities, strategic partnerships formed by the public and private sector could present benefits that can accrue to a sustainable tourism development, as long as a balance is struck between economic prosperity, environmental protection and social equity, and such tourism development is able to facilitate the social, economic and environmental well-being of a region (Nunkoo \& Smith, 2013).

Furthermore, the role of the community in the identification and the decision-making process of all stakeholders involved in the use and management of heritages or preserved tourism sites, is crucial in the sustainable management and conservation of these resources (Enongene \& Griffin, 2018). Tourism networks also provide significant positive value for driving innovation (Zach \& Racherla, 2011). In addition, the notion of inter-sector collaboration may lead to the pooling of knowledge, expertise, capital and other resources, greater coordination of relevant policies, increased acceptance of the resulting policies, and more effective implementation (Timothy, 1999).

\subsection{Cooperation versus Competition}

Although successful tourism development requires a great deal of collaboration, many authors highlight the barriers or challenges to successful partnerships (Bramwell \& Sharman, 1999; Yuksel \& Yuksel, 2005; Wong, Mistilis \& Dwyer, 2011). Wong, Mistilis and Dwyer (2011) identify the barriers to collaboration among ASEAN network partners as a desire to maintain control, coupled with changing priorities, a lack of coordination among government departments, a lack of collaborative mindset in some areas, some degree of competition among members, and a lack of private sector involvement.

In a hyper-competitive tourism sector, pure competition is not the only way to achieve a sustainable competitive advantage at the destination level, but in many cases, collaborative and cooperative logics should be undertaken by decision makers both within destinations (i.e. between public and private stakeholders) and among destinations (e.g. between NTOs or relevant DMOs) (Hoppen, Browna \& Fyall, 2014). The cooperative behavior and the competitive approach adopted by some tourism organizations, depending on their marketing campaign, is a good illustration of the coopetition relationship. This behavior of coopetition 
supports the notion that an enhanced competitive position can be achieved through the pursuit of collaborative advantage (Fyall, Garrod \& Wang, 2012). A strategic and inclusive mindset is necessary for the design and implementation of effective governance structures for collaboration, as well as to establish a suitable means of measuring and monitoring performance (Morgan et. al., 2012). Unlike resource dependency, however, strategic management theory emphasizes the need for collaboration between organizations to develop mutual trust and commitment, both of which can be critical to fulfill the direction and ambitions of NTOs and DMOs. The coopetition perspective recognizes the need for more complex descriptions of markets and business models, where cooperation and competition merge together, and actors' roles, processes and objectives become more complex (Wang \& Krakover, 2008; Wong, Mistilis \& Dwyer, 2011).

\section{Research Methodology}

A mixed methods design, employing both qualitative and quantitative approaches, is used in this study in order to address the different types of questions (Creswell \& Clark, 2007, p. 118). The quantitative phase includes a perception survey of 480 samples at the time of visiting Thailand, Lao, Vietnam and Cambodia, with a mix of Asian and Western travelers. The qualitative phase is used to explore tourism insights, derived from 10 in-depth interviews with NTOs or DMOs from Thailand, Lao, Vietnam and Cambodia. This paper presents only partial results from the quantitative and qualitative stages, with an aim to provide a framework for the ASEAN brand.

\section{Results}

\subsection{Quantitative Findings}

The majority of Asian travelers had previously traveled to ASEAN destinations approximately 4 times. Most of them organized their own trips and stayed in hotels. The average spending for the whole trip was US $\$ 360$. The internet was the main source of information for planning a trip. Most of the respondents travelled with their family during visits to ASEAN destinations. The Western travelers had previously visited ASEAN destinations approximately 5 times. Most of them organized their own trips and stayed in hotels. The average spending for the whole trip was US\$1,650. The internet was also the main source of information for planning their trip. Most of them traveled alone to ASEAN destinations.

The overall findings of the survey indicated that authenticity of the destination was perceived as the holistic value of ASEAN destinations for both Asian and Western travelers. For Asian travelers, unique and diversified cultures, as well as creative industries, were the main factors that motivated them to visit ASEAN destinations. As for Western travelers, sustainable creative activities that included cultural tourism resources, and a degree of interaction with the locals tended to affect their intention to travel to ASEAN destinations. These findings demonstrate that both motivation and involvement are important antecedents of tourist value perceptions of destination value (Prebensen et. al., 2013).

\subsection{Qualitative Findings}

The key findings from the in-depth interviews suggest that NTOs and DMOs regard themselves as being a promoter and facilitator of tourism, more than a policy maker. In spite of different levels of perception on sustainability issues that are important for development of tourism held by NTOs and DMOs of the four countries, all of them expressed concerns over the problem of tourism exploitation. They placed high priority on long-term economic opportunities for tourism, by minimizing environmental damage and preserving local cultural heritage. 
With extensive experience in the tourism industry, all NTOs and DMOs recognized the need to collaborate across sectors. Ironically, due to the proximity of destinations within the ASEAN region, with similar tourism products, most NTOs and DMOs found that competition among ASEAN countries was inevitable. They admitted that the task of building a positive image of ASEAN destinations, while differentiating themselves from competitors, was a key challenge. Nevertheless, all NTOs and DMOs agree that a collaborative approach to the sustainable management of ASEAN destinations is a prerequisite to the success of the ASEAN brand. Some collaboration among member countries include co-organizing familiarization trips, tourism events, conferences, exhibitions and so on. However, some of them also noted that a lack of funding hinders these activities in many areas.

\subsection{Conceptualizing the ASEAN Brand Framework}

From the literature review and the research results, this paper proposes a framework that displays the collaboration mechanism of the ASEAN tourism brand, shown in Figure 1. The integrative framework of the ASEAN tourism brand captures the unique features of the coopetition concept, with all 10 member countries working to promote the ASEAN brand identity.

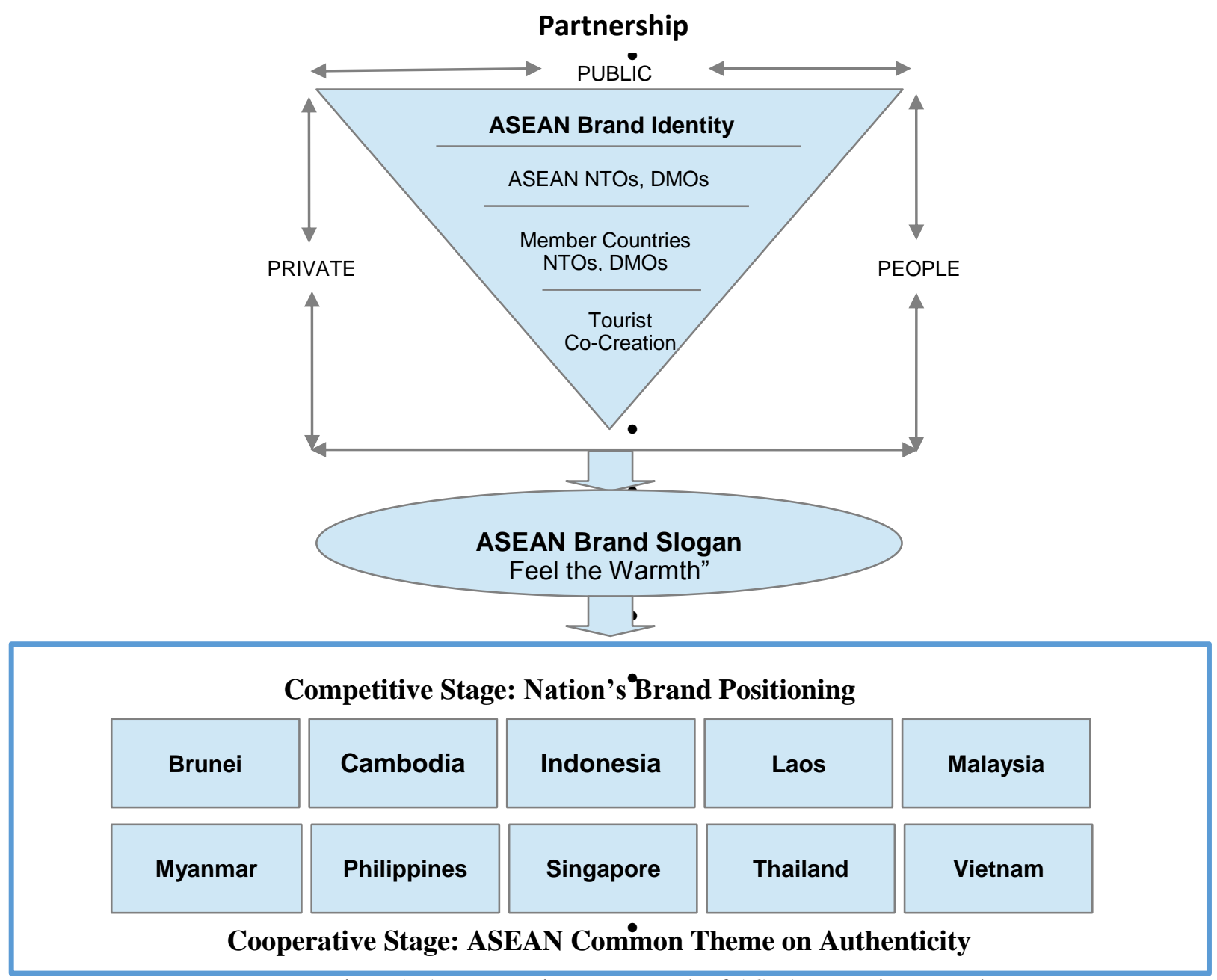

Figure1. An Integrative Framework of ASEAN Tourism Brand 


\section{Discussion}

The proposed framework emphasizes the environments in which strategic partnerships of Public, Private and People within the communities (PPP Partnership) takes place. It also highlights the interaction among actors at the regional, national and tourist level. This illustrates the integration between the competitive and cooperative environments. In the competitive setting, the NTOs and DMOs of each nation attempt to differentiate their brand slogans based on their position. On the other hand, during the cooperative stage, the NTOs or DMOs must work in collaboration, to act as the manager of the ASEAN region as a whole, to ensure the authenticity, as the holistic perceived value of the destinations, can be delivered consistently and sustainably.

With the involvement of several stakeholders, it is challenging to find common ground among the various agendas of the ASEAN countries (Bornhorst, Ritchie \& Sheehan, 2010; Sautter \& Leisen, 1999). In promoting ASEAN as one single destination brand to global tourists, it is essential that the ASEAN brand is projected as a holistic brand that reflects the essence of authenticity of the region, which represents the common value perceived by ASEAN travelers. Therefore, ASEAN NTOs and DMOs should work together to create a more cohesive and holistic destination marketing paradigm (Pike \& Page, 2014). Thus, it is vital that each nation within the ASEAN region must accept the boundary and strategic positioning of the destination as a whole, whether this is simply through the use of the ASEAN brand slogan or the development of a wider strategy. Considering the interdependence and complementarity of the tourism sector, Chim-Miki and Batista-Canino (2017) highlight that coopetition represents the key organizational behavior of tourism stakeholders. In achieving unity of the ASEAN brand, it is important that NTOs and DMOs work together with other tourism stakeholders, both in the public, private and community sectors, toward the achievement of "collaborative advantage", rather than "competitive advantage" (Wang \& Fesenmaier, 2007; Wang \& Xiang, 2007). One way of achieving a balanced stakeholder relationship is by engaging a strategic PPP partnership. The proposed framework is therefore seen as transformative in its ability to bring about collaborative efforts and to ultimately achieve a coherent and sustainable ASEAN brand.

\section{Conclusion}

The present study highlights the importance of achieving common goals through the simultaneous pursuit of cooperative efforts and competition among tourism stakeholders across the ASEAN region. In this sense, the actors in the tourism industry need to cooperate at the destination level and tend to compete at the local level (Pesämaa \& Erikson, 2010). In addition, the moderating effect of coopetition helps to manage relationships by motivating through competition and enabling the partners to co-create the ASEAN brand (Gnyawali, Madhavan, He \& Bengtsson, 2016). Wong, Mistilis and Dwyer (2011) state that to achieve the goal of ASEAN in economic integration and sustainable tourism development, continuous efforts are required to establish, promote and protect the common interests of member countries. Policymakers of the ASEAN tourism industry should also strive to achieve a balance between the pragmatism and mechanisms when implementing policies. ASEAN NTOs must manage this process to make sure that the NTOs within the member countries understand that each member nation must contribute to the total value creation for the ASEAN destination as a whole, giving rise to a partially convergent interest and goal structure where both competitive and cooperative issues are simultaneously present and strictly interconnected (McCamley \& Gilmore, 2016).

As set forth in the ASEAN Tourism Marketing Strategy 2017-2020, strong and strategic partnerships offer the only opportunity for the success of ASEAN NTOs. Thus, the integrative ASEAN brand framework suggested in this paper is seen as an opportunity to address the problem of the complexity of destination management to meet the challenge of establishing and promoting a strong ASEAN brand. This may be the solution for shaping the future of sustainability for ASEAN destinations. 


\section{References}

ATMS (2017). ASEAN Tourism Marketing Strategy 2017-2020. The ASEAN Secretariat: Jakarta.

ATSP (2016). ASEAN Tourism Strategic Plan 2016-2025. The ASEAN Secretariat: Jakarta.

Bornhorst, T., Ritchie, J. R. B. and Sheehan, L. (2010). Determinants of Tourism Success for DMOs and Destinations: An Empirical Examination of Stakeholders' Perspectives. Tourism Management, 31, 572-589.

Bramwell, B. and Sharman, A. (1999). Collaboration in Local Tourism Policymaking. Annals of Tourism Research, 26(2), 392-415.

Brida, J. G. and Aguirre, S. Z. (2010). Economic Impacts of Cruise Tourism: The Case of Costa Rica. Anatolia, 21(2), 322-338.

Cai, L. (2002). Cooperative Branding for Rural Destinations. Annals of Tourism Research, 29(3), 720-742.

Chim-Miki, A. F., Batista-Canino, R. M. (2017). Tourism Coopetition: An Introduction to the Subject and a Research Agenda, International Business Review, 26(6), 1208-1217.

Creswell, J. W. and Clark P. (2007). Designing and Conducting Mixed Methods Research (2nd ed.). Thousand Oaks, CA: Sage.

de Chernatony L. (2010). From Brand Vision to Brand Evaluation. The Strategic Process of Growing and Strengthening Brands. 3rd Ed. Butterworth Heinemann.

Dinnie, K., Melewar, T. C., Seidenfuss, K. U., Musa, G., (2010). Nation Branding and Integrated Marketing Communications: An ASEAN Perspective. International Marketing Review 27(4), 388-403.

Enongene V., Griffin K. (2018) Stakeholder Involvement: An Identified Invaluable Resource in the Management and Conservation of Ireland's Natural Religious Heritage Croagh Patrick: Insights and Challenges. Almatourism Special Issue, 8, 55-77.

Fyall, A., Garrod, B. and Wang, Y. (2012). Destination Collaboration: A Critical Review of Theoretical Approaches to Multi-dimensional Phenomenon. Journal of Destination Marketing and Management, 1, 10-26.

Gnyawali, D., Madhavan, R., He, J. and Bengtsson, M. (2016). The Competition-cooperation Paradox in Inter-firm Relationships: A Conceptual Framework. Industrial Marketing Management, 53, 7-18.

Gnoth, J. (1998). Conference Reports: Branding Tourism Destinations. Annals of Tourism Research 25, 758-760.

Grangsjo, Y. (2003). Destination Networking: Co-opetition in Peripheral Surroundings, International Journal of Physical Distribution and Logistics Management, 33(5), 427-48.

Hassan, S. (2000). Determinants of Market Competitiveness in an Environmentally Sustainable Tourism Industry, Journal on Tourism Research 38 (February), 239-245.

Hoppen, A., Browna, L. and Fyall, A. (2014). Literary Tourism: Opportunities and Challenges for the Marketing and Branding of Destinations. Journal of Destination Marketing and Management, 3, 37-47.

Morgan, N., Hastings, E. and Pritchard, A. (2012). Developing a New DMO Marketing Evaluation Framework: The Case Study of Visit Wales. Journal of Vacation Marketing, 18(1), 73-89.

Morgan N, Pritchard A and Pride R (eds) (2011) Destination Branding: Managing Place Reputation. Oxford: Butterworth-Heinemann

Moutinho L, Rate S and Ballantyne R (2013) Futurecast: An Exploration of Key Emerging Megatrends in the Tourism Arena in: Costa C, Panyik E, and Buhalis D (eds) Trends in European Tourism Planning and Organisation (pp. 313325). Bristol/Buffalo/Toronto: Channel View Publications.

McCamley, C and Gilmore, A. (2016). Strategic Marketing Planning for Heritage Tourism: A Conceptual Model and Empirical Findings from Two Emerging Heritage Regions. Journal of Strategic Marketing, 26(2), 1-18.

Nunkoo, R. and Smith, S. (2013). "Political Economy of Tourism: Trust in Government Actors, Political Support, and Their Determinants." Tourism Management, 36, 120-32.

Oliveira, E. and Panyik, E. (2014). Content, Context and Co-creation: Digital Challenges in Destination Branding With References to Portugal as a Tourist Destination. Journal of Vacation Marketing, 1-22.

Pareja-Eastway M, Chapain C and Mugnano S (2013). Success and Failures in City Branding Policies in Musterd S. and Kova'cs, Z. (eds). Place-making and Policies for Competitive Cities. (pp. 150-171). Chichester: Wiley-Blackwell.

Parker, S. 2000. Collaboration on Tourism Policy Making: Environmental and Commercial Sustainability on Bonaire, NA. In: B. Bramwell and B. Lane, Editors, Tourism Collaboration and Partnerships: Politics, Practice and Sustainability (pp.78-97), Channel View, Clevedon.

Pesamaa, O., \& Eriksson, P. E. (2010). Coopetition among nature-based tourism firms: Competition at local level and cooperation at destination level. Coopetition: Winning strategies for the 21st century, 166-182. 
Pike, S., \& Page, S. J. (2014). Destination Marketing Organizations and destination marketing: A narrative analysis of the literature. Tourism management, 41, 202-227.

Prebensen, N. K., Woo, E., Chen, J. S., \& Uysal, M. (2013). Motivation and involvement as antecedents of the perceived value of the destination experience. Journal of Travel Research, 52(2), 253-264.

Ruhanen, L. (2013). Local government: facilitator or inhibitor of sustainable tourism development? Journal of Sustainable Tourism, 21(1), 80-98.

Sautter, E. T., \& Leisen, B. (1999). Managing stakeholders a tourism planning model. Annals of tourism research, 26(2), 312-328.

Selsky, J. W., \& Parker, B. (2005). Cross-sector partnerships to address social issues: Challenges to theory and practice. Journal of management, 31(6), 849-873.

Timothy, D. J. (1999). Participatory planningA view of tourism in Indonesia. Annals of tourism research, 26(2), 371 391.

Vernon, J., S. Essex, D. Pinder, and K. Curry (2005). Collaborative Policymaking. Annals of Tourism Research, 32 (2): 325-45.

Waligo, J., Clarke, R. \& Hawkins, R, (2012). Implementing sustainable tourism: A multistakeholder involvement management framework. Tourism Management, 36: 342-353.

Webster, C., \& Ivanov, S. (2014). Transforming competitiveness into economic benefits: Does tourism stimulate economic growth in more competitive destinations?. Tourism Management, 40, 137-140.

Wang, Y. (2008). Collaborative destination marketing: Understanding the dynamic process. Journal of travel Research, 47(2), 151-166.

Wang, Y., \& Fesenmaier, D. R. (2007). Collaborative destination marketing: A case study of Elkhart county, Indiana. Tourism Management, 28(3), 863-875.

Wang, Y., \& Krakover, S. (2008). Destination marketing: Competition, cooperation or coopetition? International Journal of Contemporary Hospitality Management, 20(2), 126-141.

Wang, Y., \& Xiang, Z. (2007). Toward a theoretical framework of collaborative destination marketing. Journal of Travel Research, 46(1), 75-85.

Wong, E. P., Mistilis, N., \& Dwyer, L. (2011). A framework for analyzing intergovernmental collaboration-The case of ASEAN tourism. Tourism Management, 32(2), 367-376.

Yuksel, A., \& Yuksel, F. (2005). Managing relations in a learning model for bringing destinations in need of assistance into contact with good practice. Tourism Management, 26(5), 667-679.

Zach, F.\& Racherla, P. (2011). Assessing the Value of Collaborations in Tourism Networks: A Case Study of Elkhart County, Indiana. Journal of Travel \& Tourism Marketing, 28(1): 97-110.

Zavattaro, S. M., Daspit, J. J., \& Adams, F. G. (2015). Assessing managerial methods for evaluating place brand equity: A qualitative investigation. Tourism Management, 47, 11-21.

Zhu, Y. (2012). Performing heritage: Rethinking authenticity in tourism. Annals of Tourism Research, 39(3), 14951513. 